
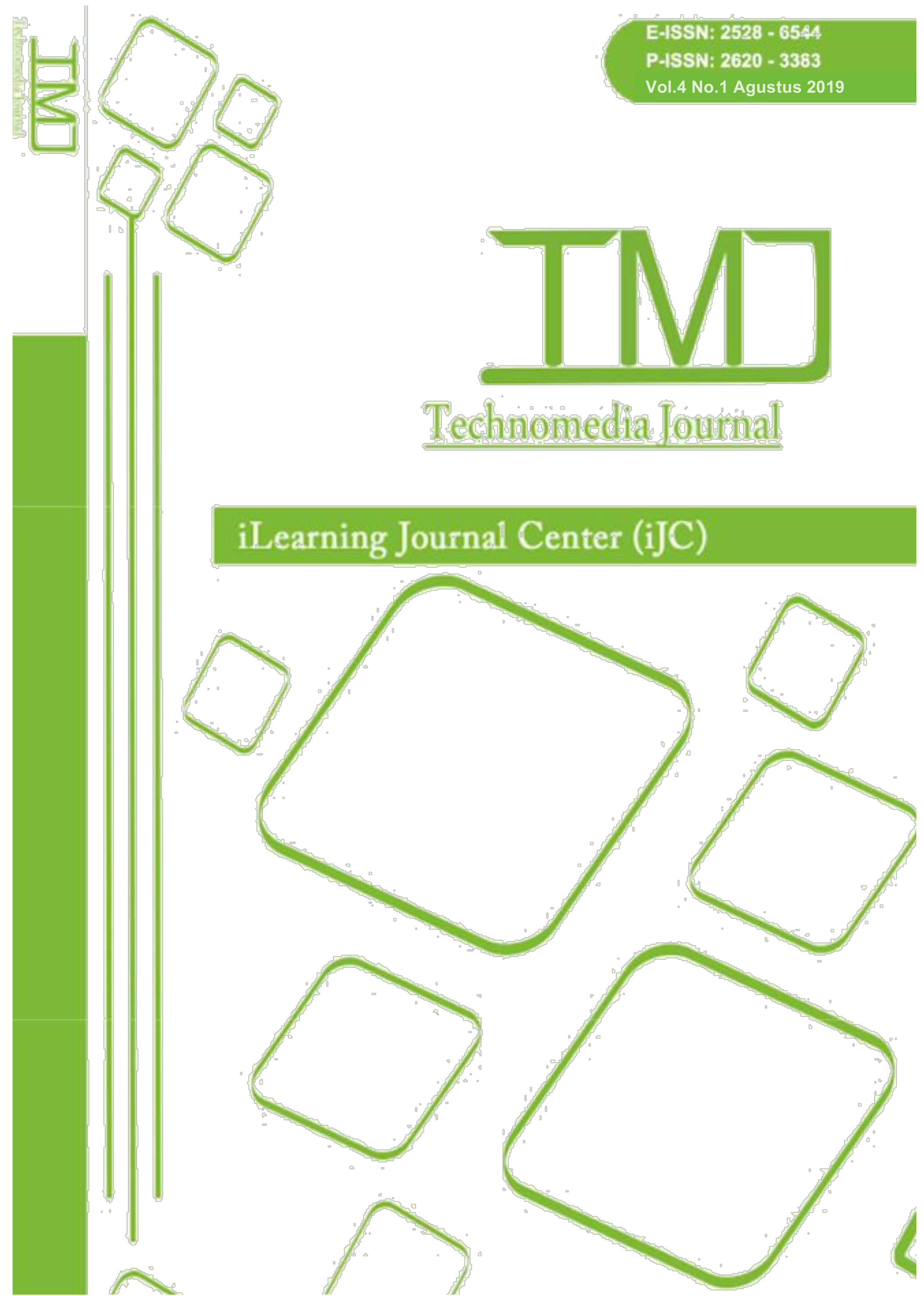


\title{
Pembuatan Aplikasi Manajemen Organisasi Swara (Amora) Berbasis Desktop
}

\author{
Abdur Rouf \\ Program Studi Sistem Informasi, Universitas Trunojoyo Madura \\ Jalan Raya Telang PO BOX 2 Kamal, Bangkalan, Jawa Timur, Indonesia \\ E-mail:170441100037@student.trunojoyo.ac.id
}

\begin{abstract}
ABSTRAK
Pemanfaatan teknologi sangatlah penting untuk pembaruan dalam pengelolaan data suatu organisasi, apalagi di era digital saat ini. Perkembangan teknologi informasi terjadi sangat cepat. Setiap saat bermunculan teknologi baru yang memberikan tambahan nilai manfaat pada teknologi terdahulu. Berdasarkan segala kelebihan yang bisa didapatkan dengan adanya teknologi komputer maka peneliti tergerak untuk membuat sebuah aplikasi yang akan digunakan untuk pengelolaan keanggotaan organisasi, dan kegiatan-kegiatan program kerja yang diagendakan. Pembuatan aplikasi ini memanfaatkan pemrograman java dengan database MySQL. Pembuatan aplikasi ini mengikuti tahapan-tahapan SDLC (System Development Life Cycle) menggunakan waterfall model karena pembuatan aplikasi dikerjakan secara linier. Langkah-langkah yang diambil dalam pembuatan aplikasi pada penelitian ini adalah Analisis Kebutuhan Sistem, Desain Sistem, dan Pengkodean. Penelitian ini berhasil membuat Aplikasi Manajemen Organisasi SWARA (AMORA) Berbasis Desktop yang dapat mengotomatisasi proses pencatatan data keanggotaan organisasi, divisi-divisi dan agenda organisasi sehingga dapat memudahkan dalam pengelolaan data keorganisasian.
\end{abstract}

Kata kunci : Aplikasi, Manajemen, Organisasi, Desktop

\begin{abstract}
The use of technology is very important for updates in data management of an organization, especially in the current digital era. The development of information technology is happening very fast. Every time new technologies emerge that provide added value to the benefits of previous technologies. Based on all the advantages that can be obtained with the existence of computer technology, researcher are interested to create an application that will be used for management of organizational membership, and the activities of the work program scheduled. This application is made using java programming with a MySQL database. This application is made following the stages of SDLC (System Development Life Cycle) using the waterfall model because the application will be done linearly. The steps taken in making the application in this study are System Requirement Analysis, System Design, and Encoding. This study succeeded in creating a Desktop-based SWARA Organization Management Application (AMORA) that can automate the process of recording organizational membership data, divisions and organizational agendas so that it can facilitate organizational data management.
\end{abstract}

Keywords: Application, Management, Organization, Desktop

1| Rouf - Pembuatan Aplikasi Manajemen Organisasi Swara (Amora)...... 


\section{PENDAHULUAN}

Salah satu masalah yang sangat umum dijumpai dalam kepengurusan organisasi adalah masalah Manajemen Organisasi. Dalam suatu organisasi biasanya pengurus akan disibukkan dengan pengelolaan keanggotaan organisasi, dan kegitan-kegiatan program kerja yang diagendakan. Namun, rata-rata pengelolaan tersebut dikerjakan secara manual melalui penulisan data di buku keorganisasian. Meskipun lainnya ada yang memakai aplikasi pencatatan misalnya Microsoft Office Excel atau lainnya namun dirasa kurang maksimal penggunaanya. Dikarenakan mulai dari penyimpanan data pada file yang terpisah-pisah atau kadang kita lupa folder tempat menyimpannya. Sehingga, pemanfaatan teknologi sangatlah penting untuk pembaruan dalam pengelolaan data suatu organisasi, apalagi di era digital saat ini.

Perkembangan teknologi informasi terjadi sangat cepat. Setiap saat bermunculan teknologi baru yang memberikan tambahan nilai manfaat pada teknologi terdahulu. Berbagai kemudahan, kenyamanan dan hal-hal lain yang tidak dapat dilakukan di masa lalu telah terjadi sekarang. Dengan kemampuannya untuk mengumpulkan seluruh pengetahuan dan mencarinya dengan cepat, telah menciptakan perubahan pada proses dan mekanisme bagaimana seseorang menerima, dan menyimpan, kemudian menyebarluaskan informasi.

\section{PERMASALAHAN}

Berdasarkan segala kelebihan yang bisa didapatkan dengan adanya teknologi komputer maka peneliti tergerak untuk membuat sebuah aplikasi yang akan digunakan untuk pengelolaan keanggotaan organisasi, dan kegitan-kegiatan program kerja yang diagendakan. Aplikasi ini dibuat agar pengurus tidak perlu mencatat data anggota serta program kerja secara manual, cukup dengan memasukkan data ke aplikasi maka aplikasi secara otomatis dapat menyimpan datanya. Oleh karena itu, peneliti merumuskan permasalahannya yaitu bagaimana pembuatan Aplikasi Manajemen Organisasi SWARA (AMORA) Berbasis Desktop?.

Adapun pembatasan masalah dalam suatu penelitian sangat diperlukan agar penelitian dapat lebih teratur dan memudahkan dalam pembahasan, sehingga tujuan penelitian dapat tercapai. Batasan-batasan masalah untuk pembuatan aplikasi ini, antara lain:

1. Target pengguna aplikasi adalah sekretaris atau user admin organisasi.

2. Aplikasi memberikan informasi profil singkat organisasi.

3. Fitur yang dibuat hanya meliputi fitur pencatatan keanggotaan, daftar divisi organisasi, dan agenda organisasi.

4. Aplikasi berbasis desktop. 


\section{METODOLOGI PENELITIAN}

Metode yang digunakan adalah sebagai berikut:

1. Metode Studi Literatur

Metode ini digunakan untuk pembelajaran dan pemahaman literatur berdasarkan permasalahan yang ada. Literatur didapatkan dari beberapa sumber seperti buku, jurnal penelitian, website dan video tutorial terkait.

2. Metode Pembuatan Aplikasi

Metode yang digunakan dalam penelitian ini adalah Research and Development (Penelitian Dan Pengembangan). Research and Development adalah proses meneliti kebutuhan pelanggan dan kemudian mengembangkan produk untuk memenuhi kebutuhan tersebut (Gay, Mills, \& Airasian, 2012). Research and Development merupakan studi sistematik, proses pengembangan, dan evaluasi dengan tujuan menciptakan suatu dasar empiris untuk menciptakan produkproduk (Klein, 2014).

Pembuatan aplikasi ini mengikuti tahapan-tahapan SDLC (System Development Life Cycle) menggunakan waterfall model karena pembuatan aplikasi dikerjakan secara linier. Waterfal Model, salah satu model SDLC paling awal, terdiri dari lima fase berturut-turut dan mereka masing-masing: Analisis bisnis, desain, implementasi, pengujian, dan pemeliharaan (Bassil , 2012).

Langkah-langkah yang diambil dalam pembuatan aplikasi pada penelitian ini sebagai berikut :

a. Analisis Kebutuhan Sistem, bertujuan menganalisis data serta merumuskan kebutuhan-kebutuhan yang mendukung proses pembuatan aplikasi.

b. Desain Sistem, bertujuan menghasilkan gambaran diagram arus data, rancangan database dan file dari aplikasi yang akan dibuat.

c. Pengkodean, yaitu penulisan baris kode dari program aplikasi yang dirancang dan dikembangkan berdasarkan aturan bahasa pemrograman yang berlaku.

Dalam melaksanakan penelitian ini, diambil beberapa referensi sebagai dasar pelaksanaan penelitian, salah satunya adalah jurnal dengan judul Using Management Information Systems (MIS) to Boost Corporate Performance yang ditulis oleh (Mohammed \& $\mathrm{Hu}, 2015)$ dalam jurnal tersebut dibahas mengenai Sistem informasi manajemen sangat penting untuk pengembangan bisnis, dengan banyak manfaat yang mungkin dihasilkan dari itu. Manfaat ini dapat diperoleh dari aplikasi pemilik bisnis sistem informasi. Untuk dapat tetap bersaing dengan sistem informasi manajemen. Definisi Sistem informasi menurut (Shaqiri, 2014), Sistem informasi adalah sekumpulan komponen terpadu untuk mengumpulkan, menyimpan dan memproses data dan untuk mengirimkan informasi, kartu, dan produk digital. Dengan adanya pemanfaatan sistem informasi setiap transaksi bisa tercatat dengan lebih rapih 
dan mudah (Dien, 2018). Ini berkaitan dengan manajemen organisasi yang merupakan kegiatan dalam merencanakan, mengatur, serta mengendalikan arus data sumber daya dari suatu organisasi. Aplikasi yang akan dikembangkan pada penelitian ini berbasis desktop atau Application software, adalah perangkat lunak komputer yang dirancang untuk melakukan sekelompok fungsi, tugas, atau kegiatan terkoordinasi untuk kepentingan pengguna (en.wikipedia.org, 2018).

Pembuatan aplikasi ini memanfaatkan pemrograman java dengan database MySQL. Beberapa hal yang dipelajari adalah bahasa pemrograman java NetBeans dan Database MySQL, serta bagaimana membuat aplikasi manajemen organisasi di perangkat desktop menggunakan NetBeans. Bahasa pemrograman Java, berasal dari Sun Microsystems dan dirilis kembali pada tahun 1995, adalah salah satu bahasa pemrograman yang paling banyak digunakan di dunia, menurut TIOBE Programming Community Index (Redko, 2015). Kemudian, Sistem database yang umum digunakan adalah Oracle, Microsoft SQL Server, Oracle, MySQL, dan IBM IDB2. Tujuan menggunakan produk yang berisi platform MySQL dimotivasi oleh fakta bahwa sistem basis data ini semakin banyak digunakan dalam produksi (STROE , 2011).

Dari metode dan referensi yang digunakan, peneliti mulai merumuskan kebutuhankebutuhan aplikasi yang akan dibuat. Analisis kebutuhan fungsional adalah pembahasan tentang fitur-fitur pada aplikasi yang akan dibuat. Fitur-fitur tersebut yaitu:

- Aplikasi dapat menampilkan Halaman Utama Daftar Menu Aplikasi

- Aplikasi dapat menampilkan Halaman Menu Home

$>$ Aplikasi dapat menampilkan profil Organisasi

$>$ Aplikasi dapat menampilkan visi dan misi Organisasi

$>$ Aplikasi dapat menampilkan struktur Organisasi

- Aplikasi dapat menampilkan Halaman Menu Membership

$>$ Aplikasi dapat menambahkan data keanggotaan

$>$ Aplikasi dapat mengubah data keanggotaan

$>$ Aplikasi dapat menghapus data keanggotaan

$>$ Aplikasi dapat menampilkan detail data keanggotaan

- Aplikasi dapat menampilkan Halaman Menu Division

$>$ Aplikasi dapat menambahkan data Divisi Organisasi

$>$ Aplikasi dapat mengubah data Divisi Organisasi

$>$ Aplikasi dapat menghapus data Divisi Organisasi

$>$ Aplikasi dapat menampilkan detail data Divisi Organisasi

- Aplikasi dapat menampilkan Halaman Menu Agenda

$>$ Aplikasi dapat menambahkan data Agenda

$>$ Aplikasi dapat mengubah data Agenda

$>$ Aplikasi dapat menghapus data Agenda

$>$ Aplikasi dapat menampilkan detail data Agenda

- Aplikasi dapat menampilkan Halaman Menu Info 
Aplikasi dapat menampilkan informasi pengembang

Aplikasi dapat menampilkan informasi bantuan aplikasi

- Aplikasi dapat menampilkan Halaman Menu Exit

Aplikasi dapat melakukan konfirmasi keluar Aplikasi

- Aplikasi dapat menutup Jendela Antarmuka Aplikasi

Analisis kebutuhan non fungsional adalah pembahasan atau paparan mengenai kebutuhan perangkat-perangkat yang mendukung dalam proses pembuatan aplikasi. Kebutuhan-kebutuhan non fungsional dalam penelitian ini yaitu:

a. Perangkat Keras (Hardware)

Perangkat keras yang digunakan dalam pembuatan dan implementasi Aplikasi Manajemen Organisasi SWARA memiliki spesifikasi sebagai berikut:

Tabel 1. Spesifikasi Hardware

\begin{tabular}{lll}
\hline No & Kategori Hardware & Spesifikasi Hardware \\
\hline $\mathbf{1}$ & Manufacturer (PC) & Lenovo \\
\hline $\mathbf{2}$ & Model & Ideapad 320 \\
\hline $\mathbf{3}$ & Processor & AMD A9-9420 APU 7 ${ }^{\mathrm{TH}}$ GEN \\
\hline $\mathbf{4}$ & Memory (RAM) & DDR4 4GB \\
\hline $\mathbf{5}$ & Graphic Card & AMD RADEON 530 \\
\hline $\mathbf{6}$ & Hard Disk & 1 TB
\end{tabular}

b. Perangkat Lunak

Perangkat lunak yang digunakan dalam pembuatan aplikasi adalah sebagai berikut:

1. Sistem Operasi

Pembuatan aplikasi dikembangkan pada sistem operasi Windows 10 Pro (64 bit).

2. Bahasa Pemrograman Java

Modul pemrograman java yang digunakan yaitu Java Development Kit (JDK) dan Java Runtime Environment (JRE).

3. NetBeans

Dalam pembuatan aplikasi ini menggunakan IDE NetBeans 8.2

Tabel 2. Spesifikasi Software

\begin{tabular}{lll}
\hline No & Kategori Software & Spesifikasi Software \\
\hline $\mathbf{1}$ & Operating System (OS) & Windows 10 Pro (64 bit) \\
\hline $\mathbf{2}$ & Bahasa Pemrograman & Java \\
\hline $\mathbf{3}$ & Editor & NetBeans IDE 8.2 \\
\hline $\mathbf{4}$ & Database Server & MySQL GUI 5.1 \\
\hline
\end{tabular}


5 Image Editor

$6 \quad$ Image Ikon
- $\quad$ Adobe Photoshop CS6

- CorelDRAW X7

Perancangan Sistem :

Tabel 3. Struktur Tabel Anggota

\begin{tabular}{llll}
\hline Field & Type & Key & Extra \\
\hline id_anggota & $\operatorname{int}(11)$ & primary key & auto_increment \\
\hline nama & $\operatorname{varchar}(100)$ & & \\
\hline tgl_lahir & $\operatorname{varchar}(20)$ & & \\
\hline jenis_kelamin & varchar(10) & & \\
\hline alamat & varchar(200) & & \\
\hline
\end{tabular}

Tabel 4. Struktur Tabel Divisi

\begin{tabular}{llll}
\hline Field & Type & Key & Extra \\
\hline kode_divisi & $\operatorname{int}(11)$ & primary key & auto_increment \\
\hline nama_divisi & varchar(100) & & \\
\hline
\end{tabular}

Tabel 5. Struktur Tabel Agenda

\begin{tabular}{llll}
\hline Field & Type & Key & Extra \\
\hline kode_agenda & $\operatorname{int}(11)$ & primary key & auto_increment \\
\hline nama_agenda & $\operatorname{varchar}(100)$ & & \\
\hline tanggal_agenda & $\operatorname{varchar}(20)$ & & \\
\hline
\end{tabular}

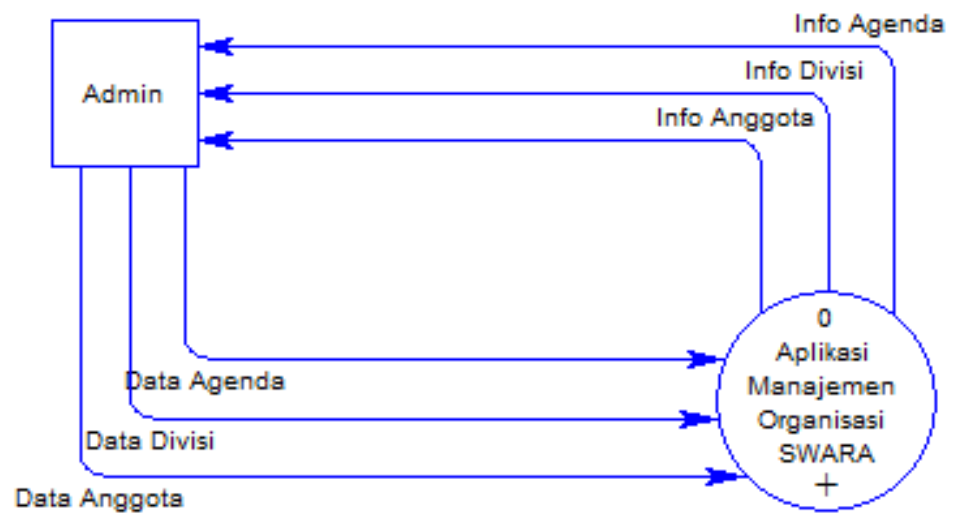

Gambar 1. Diagram Konteks 
Diagram konteks yaitu diagram untuk memberikan gambaran sistem secara umum sebelum aplikasi dibuat.

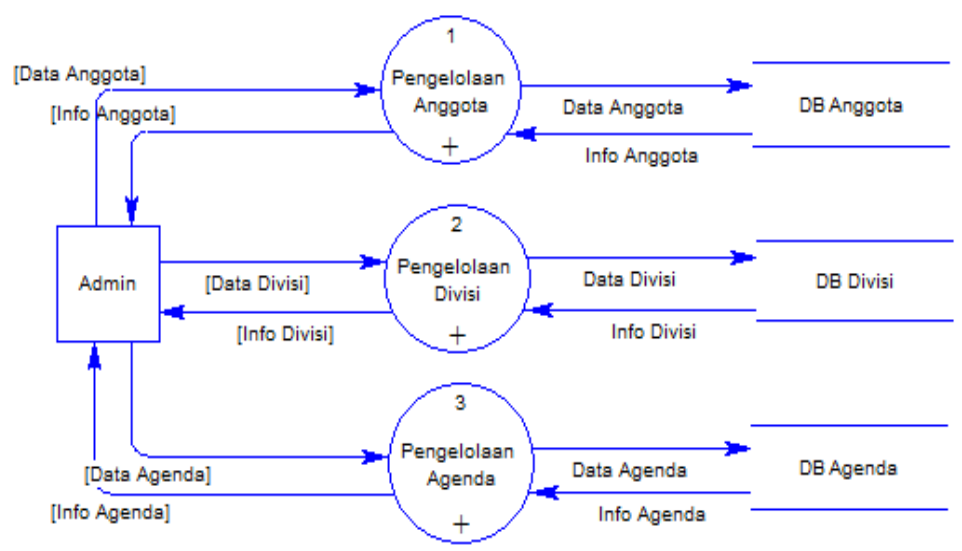

\section{Gambar 2. DFD Level 0}

DFD Level 0 yaitu diagram yang memberikan gambaran arus data dari proses umum yang pertama.

Selanjutnya, DFD Level 1 yaitu diagram yang memberikan gambaran arus data secara lebih detail, dijelaskan bahwa admin memasukkan data ke dalam aplikasi dengan proses input, update dan data tersebut disimpan dalam database. Dalam aplikasi ini Admin memberikan masukan data ke dalam sistem berupa data organisasi yang juga dapat diperbarui dan data organisasi tersebut disimpan dalam database.

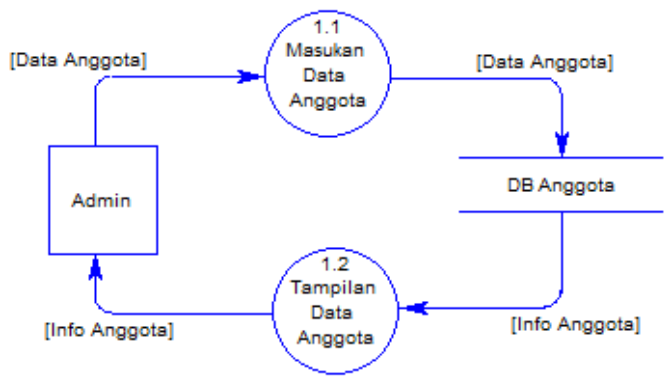

Gambar 3. DFD Level 1 (Pengelolaan Anggota) 


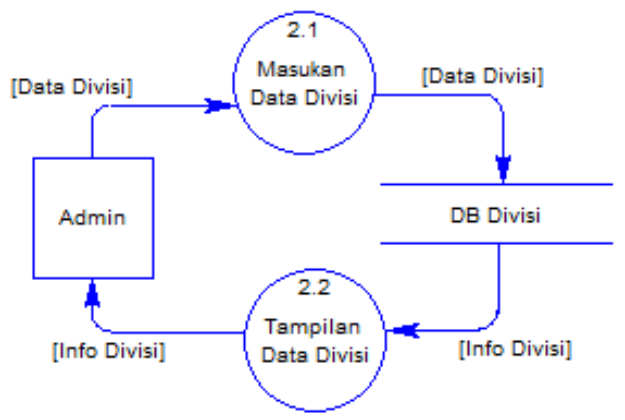

Gambar 4. DFD Level 1 (Pengelolaan Divisi)

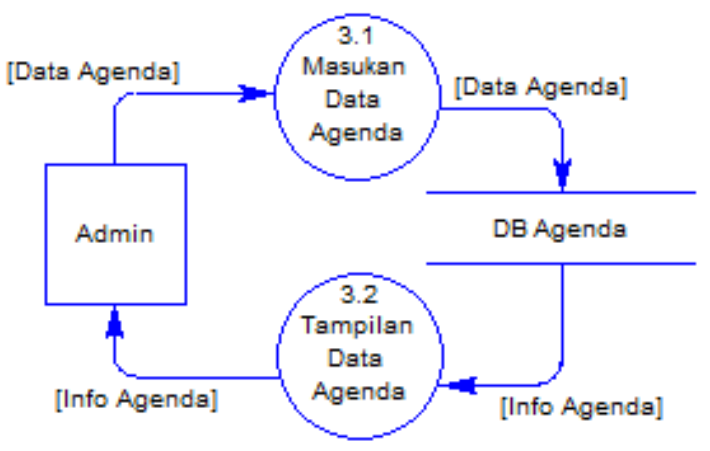

Gambar 5. DFD Level 1 (Pengelolaan Agenda)

\section{HASIL DAN PEMBAHASAN}

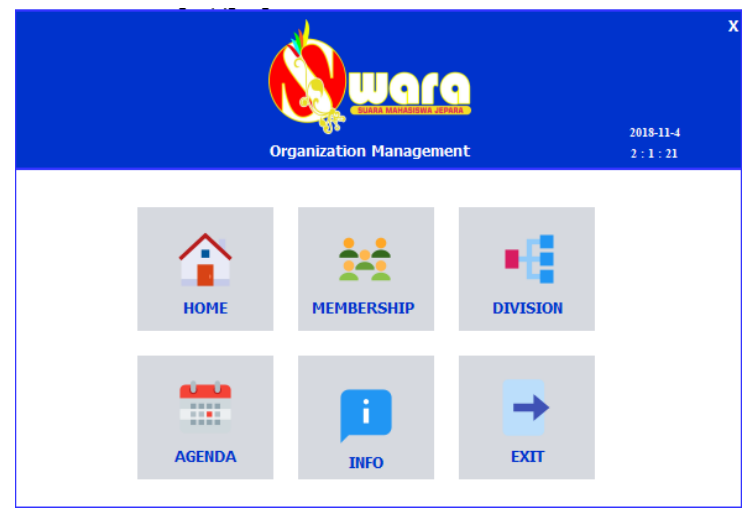

Gambar 6. Antarmuka Halaman Utama

Berdasarkan Gambar 6. Halaman Utama terdapat menu Home, Membership, Division, Agenda, Info, dan Exit. 


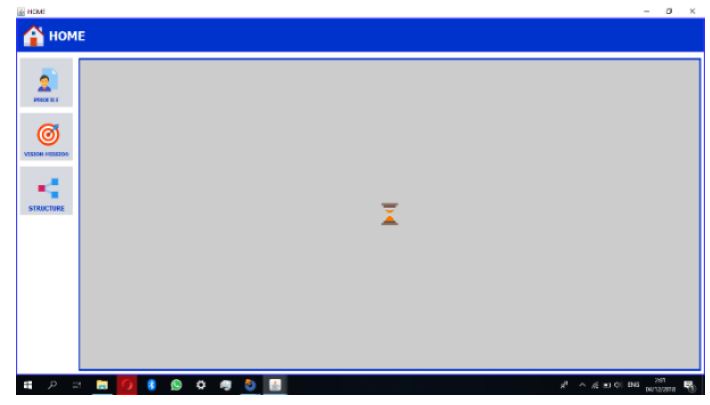

Gambar 7. Antarmuka Menu Home

Berdasarkan Gambar 7. Tampilan Menu Home terdapat 3 fitur meliputi tampilkan Profile, Vision-Mission, dan Structure organisasi.

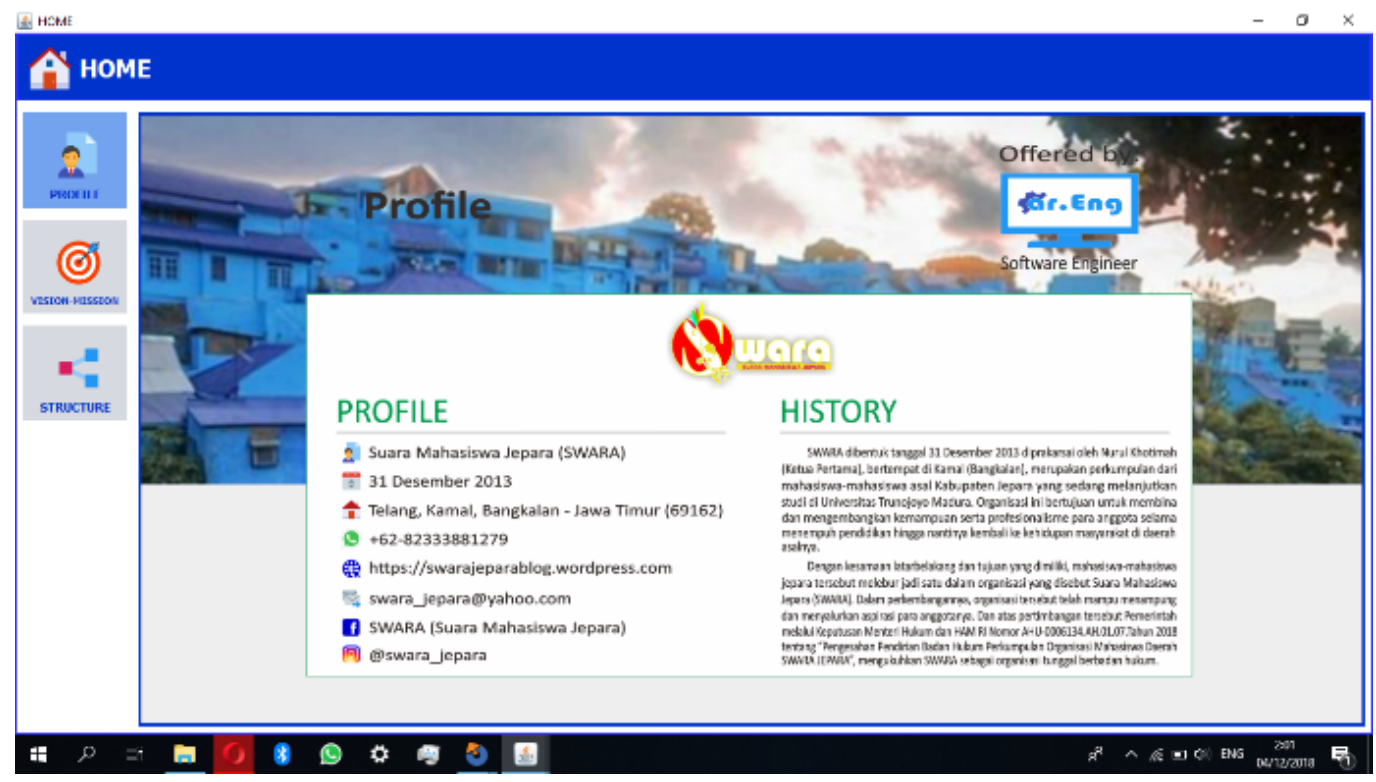

Gambar 8. Tampilan Fitur Profile

Berdasarkan Gambar 8. Tampilan Fitur Profil Organisasi SWARA meliputi Profile dan History.

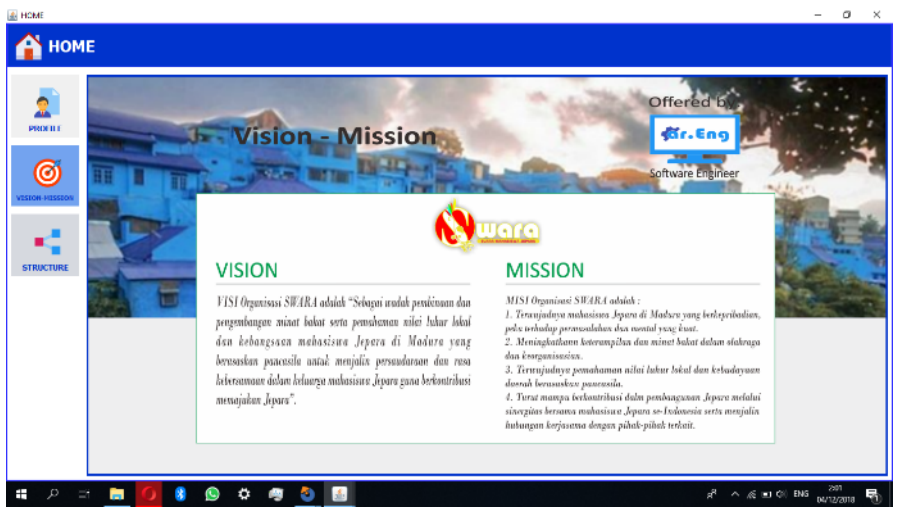

Gambar 9. Tampilan Fitur Vision-Mission

Berdasarkan Gambar 9. Tampilan Fitur Vision-Mission Organisasi SWARA 
memberikan informasi tentang visi dan misi organisasi.

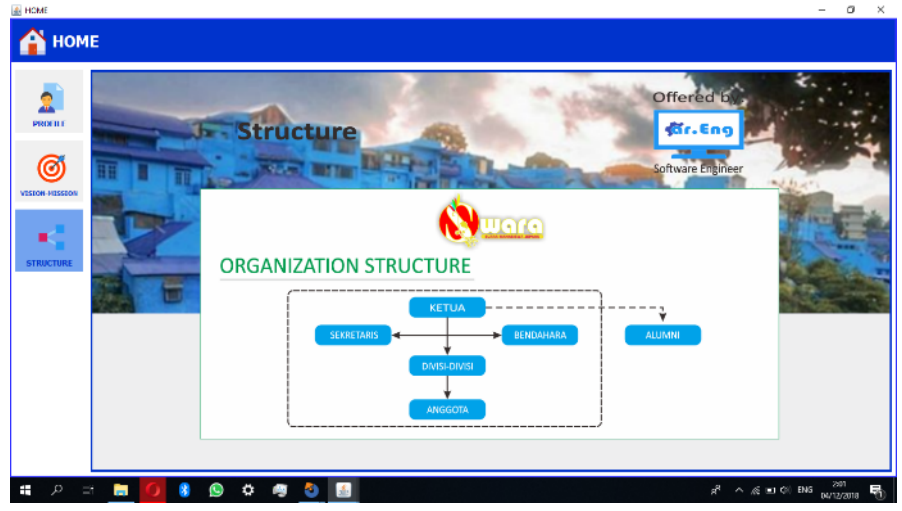

Gambar 10. Tampilan Fitur Structure

Berdasarkan Gambar 10. Tampilan Fitur Structure Organisasi SWARA menampilkan kerangka kepengurusan.

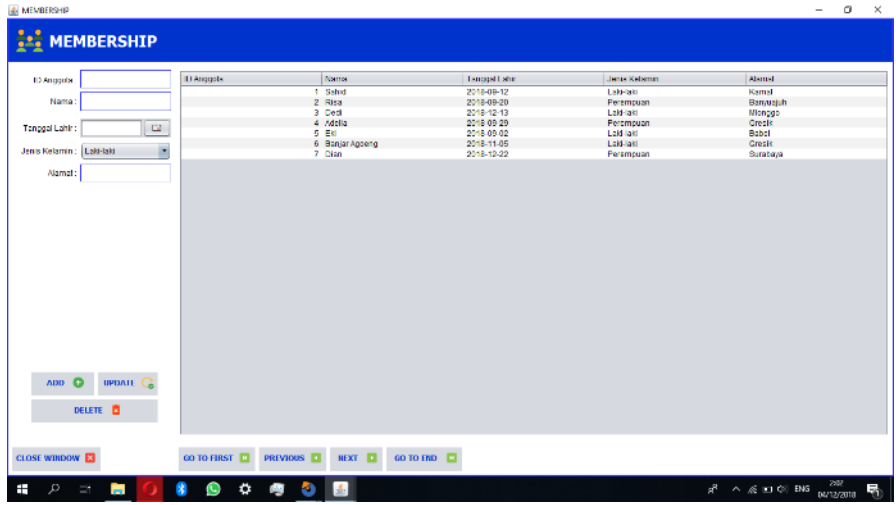

Gambar 11. Implementasi Antarmuka Menu Membership

Berdasarkan Gambar 11. Tampilan Menu Membership dapat menambahkan, mengubah, menghapus data, dan menampilkan data keanggotaan. Data yang ditambahkan berupa id anggota, nama, tanggal lahir dari anggota, jenis kelamin anggota, dan alamat.

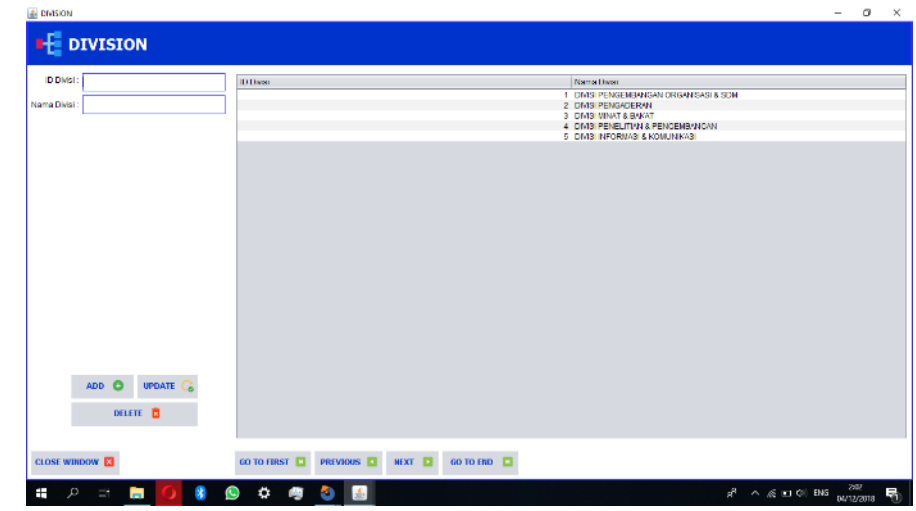

Gambar 12. Implementasi Antarmuka Menu Division 
Berdasarkan Gambar 12. Tampilan Menu Divison dapat menambahkan, mengubah, menghapus data, dan menampilkan nama-nama divisi.

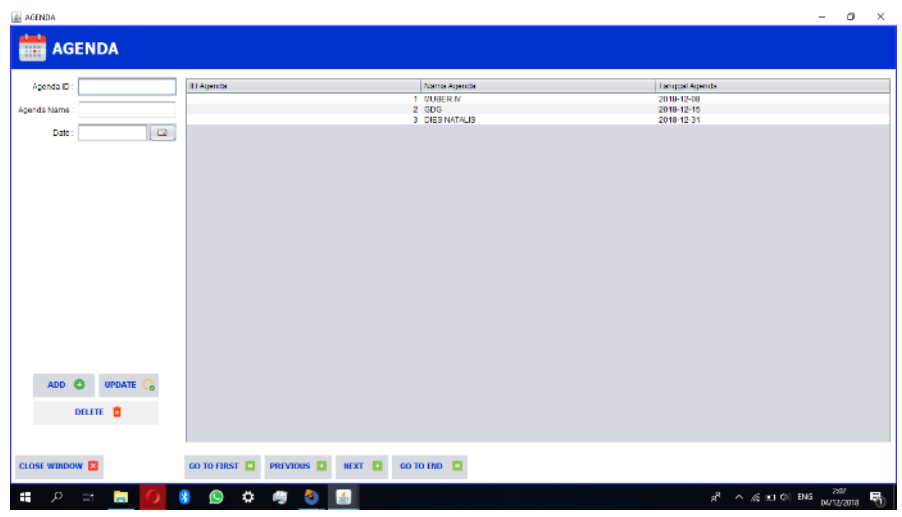

Gambar 13. Implementasi Antarmuka Menu Agenda

Berdasarkan Gambar 13. Implementasi Menu Agenda dapat menambahkan, mengubah, menghapus data, dan menampilkan data agenda.

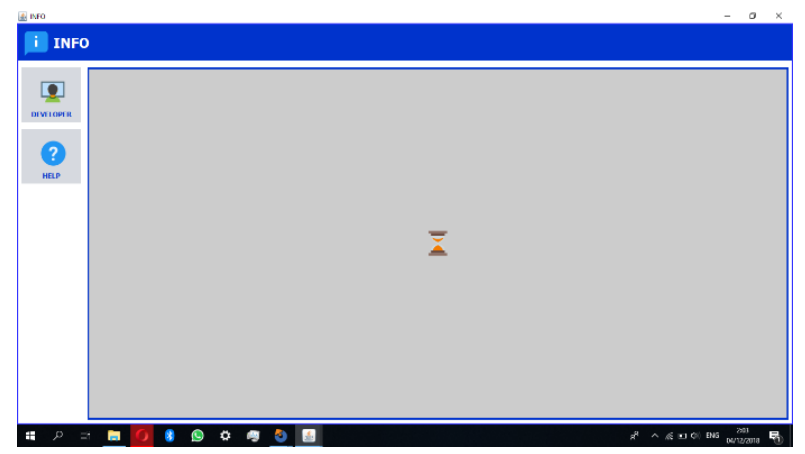

Gambar 14. Implementasi Antarmuka Menu Info

Berdasarkan Gambar 14. Tampilan Menu Info terdapat fitur info developer dan fitur info bantuan aplikasi.

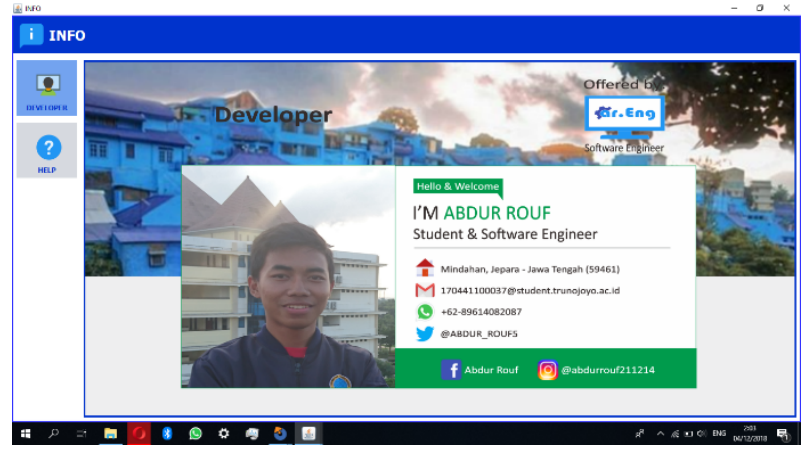

Gambar 15. Tampilan Fitur Developer

Berdasarkan Gambar 15. Tampilan Fitur Developer dapat menampilkan informasi profil tentang pengembang. 


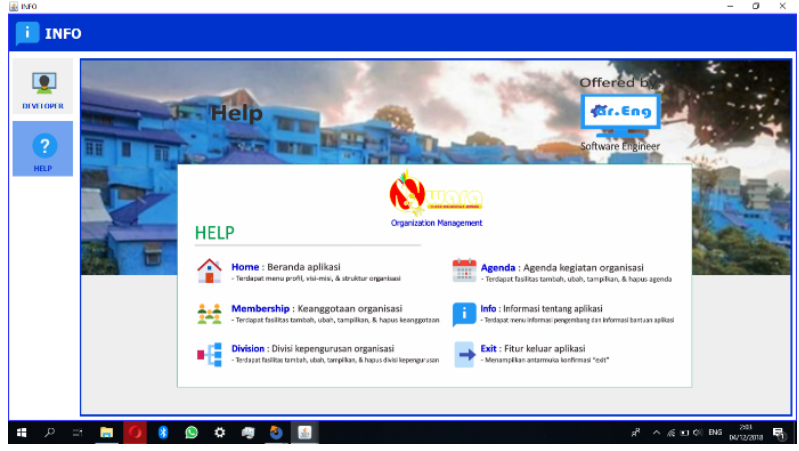

Gambar 16. Tampilan Fitur Help

Berdasarkan Gambar 16. Tampilan Fitur Help dapat menampilkan informasi bantuan aplikasi.

\section{EXIT}

Do you want to exit?

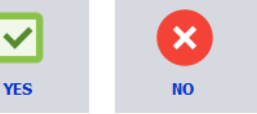

Gambar 17. Implementasi Antarmuka Menu Konfirmasi Exit

Berdasarkan Gambar 17. Tampilan Menu Konfirmasi Exit dapat menampilkan kotak pilihan konfirmasi exit antara pilihan YES atau NO. 


\section{KESIMPULAN}

Dari analisis perancangan dan implementasi, serta hasil penelitian Pembuatan Aplikasi Manajemen Organisasi SWARA (AMORA) Berbasis Desktop ini, dapat disimpulkan bahwa :

1. Penelitian ini berhasil membuat Aplikasi Manajemen Organisasi SWARA (AMORA) Berbasis Desktop yang dapat mengotomatisasi proses pencatatan data keanggotaan organisasi, divisi-divisi dan agenda organisasi sehingga dapat memudahkan dalam pengelolaan data keorganisasian.

2. Aplikasi dapat menampilkan informasi tentang organisasi meliputi profil singkat dan sejarah organisasi, paparan visi dan misi organisasi, serta struktur organisasi.

\section{SARAN}

Setelah dilakukan penelitian pada Pembuatan Aplikasi Manajemen Organisasi SWARA (AMORA) Berbasis Desktop ini, terdapat beberapa saran yang diharapkan dapat menjadi masukan untuk meningkatkan usabilitas dan efektifitas penggunaan aplikasi nantinya, yaitu :

1. Kedepannya aplikasi ini dapat dikembangkan lagi pada komponen tampilan atau layout menu pada aplikasi.

2. Diharapkan pada pengembangan aplikasi ini nantinya dapat menggunakan metode pengembangan sistem yang berbeda, dan menggunakan relasi antar data yang lebih baik.

3. Ditambahkan fitur yang lebih banyak lagi yang berkaitan tentang manajemen organisasi.

\section{DAFTAR PUSTAKA}

[1] Gay, L. R., Mills, G. E., \& Airasian, P. W. (2012). Educational Research : Competencies for Analysis and Applications (10th Edition). New York: Pearson Education. Inc.

[2] Klein, J. D. (2014). Design and Development Research. Paper presented at AERA, 1-5

[3] Bassil , Y. (2012, May). A Simulation Model for the Waterfall Software Development Life Cycle. International Journal of Engineering \& Technology (iJET),, 2, -. Retrieved from http://iet-journals.org/archive/2012/may_vol_2_no_5/255895133318216.pdf

[4] Mohammed, A.-N. N., \& Hu , W. (2015, October). Using Management Information Systems (MIS) to Boost Corporate Performance. International Journal of Management Science and Business Administration, 55-61.

[5] Shaqiri, A. B. (2014, July). Management Information System and Decision-Making. Academic Journal of Interdiciplinary Studies MCSER Publishing, Rome-Italy, 3, -.

[6] Dien, A., Rais, N., \& Rechandini, A. (2018). Pengembangan Sistem Informasi 
Monitoring Transaksi Gas Elpiji PT. Amrin Jami Indonesia Tigaraksa. Technomedia Journal, 3(1), 73-83. https://doi.org/https://doi.org/10.5281/zenodo.1409449

[7] en.wikipedia.org. (2018, December 4). Application_software. Retrieved from Wikipedia: https://en.wikipedia.org/wiki/Application_software

[8] Redko, A. (2015). Advanced Java : Preparing You for Java Mastery. Attica: Exelixis Media P.C.

[9] STROE, I.-S. (2011). MySQL databases as part of the Online Business, using a platform based on Linux . Database Systems Journal , 3-12. 